Research article

\title{
Comparative study between two media on in vitro maturation rate of local buffalo oocytes
}

\author{
Ihsan A. Habeeb ${ }^{1} \quad$ Suhailla O. Hussain ${ }^{2}$ \\ ${ }^{1-}$ College of Veterinary Medicine, University of Basrah, Iraq \\ ${ }^{2-}$ College of Veterinary Medicine, University of Baghdad, Iraq
}

(Received 20/7/2017, Accepted 29/12/2017)

\begin{abstract}
Availability of developmentally competent buffalo oocytes is critical for in vitro embryo production and application of related biotechniques. The present study has been undertaken to study the effect of TCM-199 and synthetic oviduct fluid (SOF) medium with supplements (10\% Bovine serum albumen (BSA), $10 \mathrm{IU} / \mathrm{ml}$ follicle stimulating hormone FSH) with100 IU/mL penicillin, $100 \mathrm{mg} / \mathrm{mL}$ streptomycin and $100 \mathrm{IU} / \mathrm{mL}$ Nystatin on maturation of buffalo oocytes in vitro. Buffalo ovaries $(n=300)$ were collected from local abattoir of Basrah within two hours of slaughter and transported immediately to the laboratory under septic condition. Follicular oocytes $(n=215)$ were recovered by aspiration and slicing method. Only normal grades(A and B) cumulus-oocyte-complexes (COCs) were incubating under $5 \%$ CO2 in air at 38.5 C for 24 hours in two media TCM199 media $(n=105)$ or SOF media $(n=110)$ oocytes adding same supplements which mention above. The percentage of oocytes maturation when using TCM-199 medium was $(33.33 \%)$ was significantly higher $(P<0.01)$ compared to those obtained with SOF medium $13.91(\%)$.
\end{abstract}

Keywords: Buffalo, Cumulus-oocyte-complexes, IVM, TCM-199, Synthetic oviduct.

\section{Introduction}

Buffaloes are reported to have low reproductive performance with inherent reproductive problems of weak/silent estrus signs, seasonal anestrous, delayed puberty, delayed first calving, late postpartum conception, a long calving interval (1) and low total number of follicles in the ovary (2). Improving the genetic potential of water buffaloes for milk and meat has been a major concern for decades in countries that produce and raise buffalo. Assisted reproductive technologies (ART), such as in vitro fertilization (IVF) (3). Has been focus the research in buffalo IVEP to solve the problems of the low rate of embryos developing to the blastocyst stage (4). Oocyte maturation can be defined as those events associated with the initiation of germinal vesicle breakdown (GVBD) and completion of first meiotic division (5). Maturation allows the oocyte to express its developmental potential after fertilization and is not merely confined to nuclear events or the ability to be fertilized (6). The developmental competence of in vitro matured oocytes was significantly lower compared to oocytes matured in vivo, even though the nuclear maturation rates were similar, due to inappropriate maturation (7) study the effect gonadotrophins with supplemented such as $20 \%$ buffalo estrous serum (BES) or fetal calf serum (FCS) adding to TCM-199 or Ham's F-10 on embryo production (8) evaluated the effects of two maturation media (TCM-199 and Ham's F-12) with and without the addition 
of estrus buffalo serum (OBS) and hormones (FSH, LH, E2) on the maturation rate of buffalo follicular oocytes. The results revealed a significant $(P<0.05)$ increase in the maturation rate when the OBS and hormones were added to TCM199 than in Ham's F-12 medium. (10) recorded comparative study between two methods in the first method the Follicular oocytes obtained by aspiration and the second was the scoring method. It was found that the scoring method was an appropriate method for high recovery of good quality oocytes per ovary as it yielded 3.85 oocytes per ovary than aspiration method (1.76 oocytes per ovary) for IVF in buffalo. (9) Compare fertilization rates following exposure of oocyte to spermatozoa from different buffalo bulls, using three sperm preparation methods. (11) Study the differences between the four seasons concerning the quality of collected oocyte, In spring months (Month 3, 4 and 5 of the year) and winter months (12, 1 and 2 of the year) the percentage of good quality oocytes was 71 and $74.6 \%$ respectively While in the summer months $(6,7$ and 8 of year) and autumn months (9,10 and 11 of year) the percentage of good quality oocytes was 50 and $56.9 \%$ respectively in vitro maturation rate of Egyptian buffalo. (8) Study the effect method harvesting on the evaluation of riverine buffalo follicular oocytes, (12) Study the effect of two media and addition of supplements or hormones to IVM medium on buffalo oocyte maturation rate after culturing the oocyte in either TCM-199 or Ham F-10 with BAS or FBS with or without hormone supplement (PMSG,FSH and E2). (13) An investigation the effect of different media on invitro maturation (IVM) and in vitro fertilization (IVF) of buffalo oocytes collected with the cumulus oocyte complex (COCs) which was allocated to three maturational media; TCM-199 supplemented with hormones (M1), TCM-199 supplemented with epidermal growth factor (M2) and m-SOF (M3) overlaid with paraffin oil before incubating. (14) conducted a study was to improve in vitro maturation and cleavage rates of buffalo oocytes by using TCM-199, Ham's F-10, MEM or FertiCult medium supplemented with either $10 \%$ FCS or $0.3 \%$ BSA. (15) Conducted study bioassay Evaluation using in vitro matured water buffalo oocytes and bull sperms to predicting fertility. (16) Study the effect of melatonin supplementation to in vitro maturation media to evaluate fertilization (IVF) rate of buffalo oocytes. (17) Study the effect of media supplements on in-vitro maturation, cleavage and embryo development of buffalo oocytes.

\section{Materials and Methods \\ Ethical approval}

The Animal Ethical Committee of Veterinary Medicine College, University of Al-Qadisiyah, Iraq, has approved the present study under permission No: 403

\section{Experimental Sample:}

A- All samples were collect from mature females of Buffalo, since the age is determined (as possible) according to the dental tables (Miller and Robertson, 1959). Abattoir female gonads Specimens were collected from Al-Basrah abattoir from January to April 2017 in an average of 3-4 visits per week as below:

B-Genitalia of female Buffalo (300 specimens) were collected directly after slaughtering by cool box from the abattoir to the Laboratory of Center Unit Research /College of Veterinary Medicine/ University of Basrah.

\section{Collection of the ovaries:}

Thirty-hundred ovaries from sexually mature buffaloes were collected within 30 minute after slaughter in the abattoir, 40 Ovaries was neglected because ovarian disease and loose during slaughtering. They were transported within $2 \mathrm{~h}$ of slaughterhouse to the laboratory in physiological normal saline $(0.9 \% \mathrm{NaCl})$ containing antibiotics $\quad(100 \quad \mu \mathrm{g} / \mathrm{ml}$ 


\section{Al-Qadisiyah Journal of Veterinary Medicine Sciences \\ (P-ISSN 1818-5746/ E-ISSN 2313-4429)}

www.qu.edu.iq/journalvm

streptomycin sulfate and $100 \mathrm{IU} / \mathrm{ml}$ penicillin) and preserved in cool boxes at 4$8{ }^{\circ} \mathrm{C}$. Upon arrival at the laboratory, foreign tissue was removed from the ovaries. Then, the ovaries were wash with $70 \%$ ethanol to control contamination, rinsed 3 times in normal saline $(0.9 \% \mathrm{NaCl})$, and finally dried with sterilized paper towels (26)

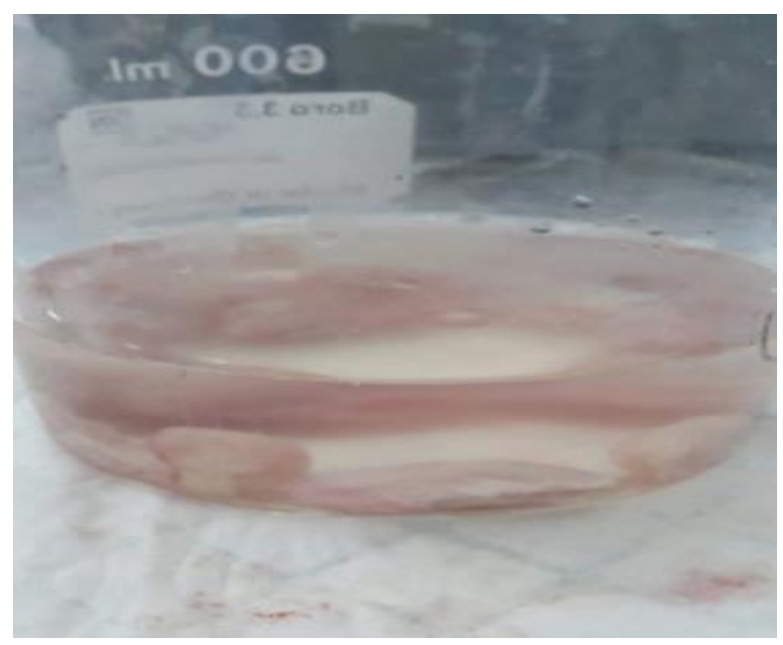

Figure (1): ovaries samples preserving in antibiotic medium

\section{Harvesting and Evaluation of Follicular Oocytes:}

Oocytes were collect by two methods aspiration and slicing (27), 100 Ovaries used in aspiration method Oocytes were aspirated from 5 to $18 \mathrm{~mm}$ as Figure (2-A, B) follicles using a different size-gauge needle attached to a 5-ml sterile syringe containing $2 \mathrm{ml}$ media with $100 \mu \mathrm{g} / \mathrm{ml}$ streptomycin sulfate as Figure (2- C). 100 $\mathrm{IU} / \mathrm{ml}$ penicillin and100 IU/mL Nystatin in a glass Petri-dishes. Oocytes were searched using a stereo zoom microscope. Furthermore, Oocytes were picked up with micropipette under stereomicroscope and transferred into another dish containing media (28). The oocytes with intact layers of cumulus cells and homogenous cytoplasm were selected for the study (26)

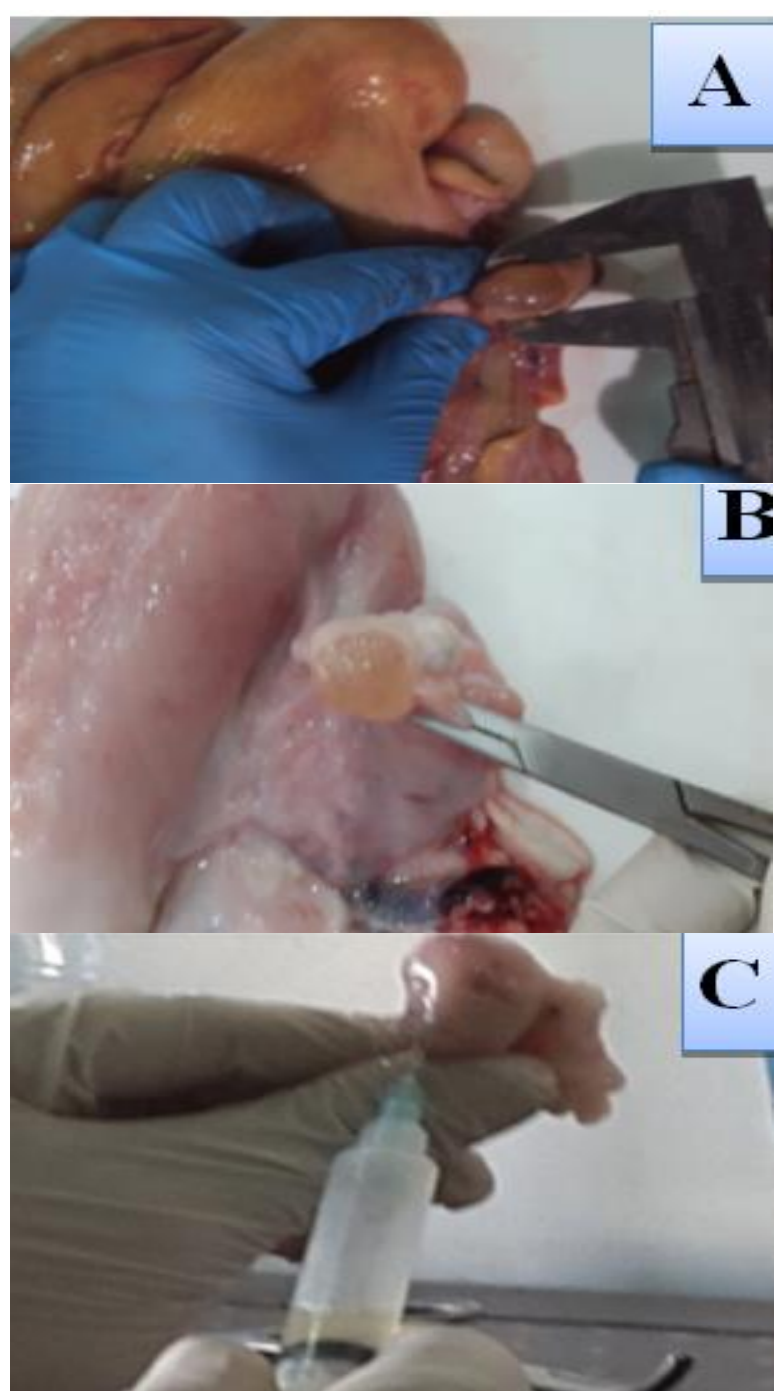

Figure (2): A follicle measurement, B ovary with large follicles $\mathbf{C}$ follicle aspiration

\section{Slicing method}

One hundred and sixty Ovaries used, Excess tissue, corpora lutea were removed, 2-4 ovaries per petri dish were sliced containing $5 \mathrm{~mL}$ of media with $100 \mu \mathrm{g} / \mathrm{ml}$ streptomycin sulfate, $100 \mathrm{IU} / \mathrm{ml}$ penicillin and100 IU/mL Nystatin, as show Figure (3). Oocytes were recovered by slicing the surface of the ovary with a single sterile surgical blade. After slicing, the ovary was thoroughly rinsed in the same petri dish by media. Were leaved to settle down at room temperature for 15 minutes. Then the media were examine under a stereomicroscope to search for COCs. $(24,29)$. 


\begin{tabular}{c}
\hline $\begin{array}{c}\text { Al-Qadisiyah Journal of Veterinary Medicine Sciences } \\
\text { (P-ISSN 1818-5746/ E-ISSN 2313-4429) } \\
\text { www.qu.edu.iq/journalvm }\end{array}$ \\
\hline
\end{tabular}

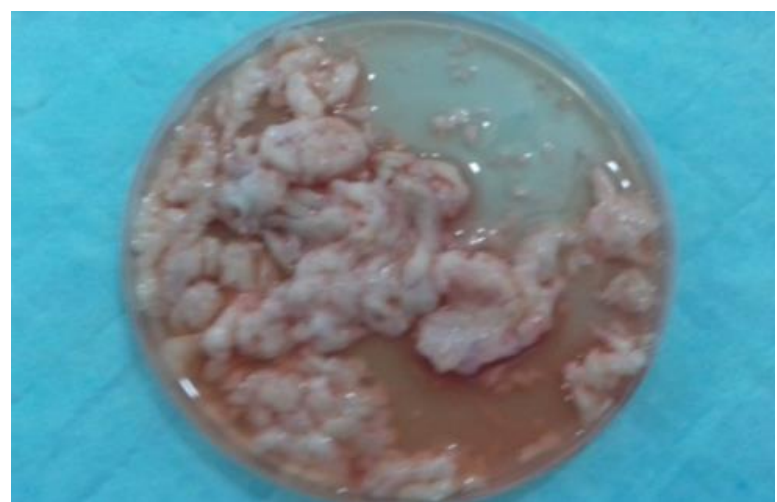

Figure (3): show Oocytes were collected by slicing method.

\section{Oocytes Maturation (IVM):}

10 ML of Maturation medium with Supplement was equilibrated for two hours in $\mathrm{CO} 2$ incubator before oocytes added (34). 215 oocytes recovery by two methods, the oocytes of Grades A and B were used for in vitro maturation. all Oocytes must be rinsed 2-3 times in same Maturation media with $100 \mathrm{IU} / \mathrm{mL}$ penicillin, $100 \mathrm{mg} / \mathrm{mL}$ streptomycin and $100 \mathrm{IU} / \mathrm{mL}$ Nystatin before oocytes added in Maturation medium, oocytes were divided into two groups according to the type of maturation medium(TCM-199 or SOF) with supplemented 10\% Bovine serum albumen (BSA), $10 \mathrm{IU} / \mathrm{ml}$ follicle stimulating hormone (FSH) as the following: Group 1: oocytes ( $\mathrm{n}=105$ Oocytes) matured using Tissue Culture Medium-199 (TCM-199, Gibco) with supplemented. Group 2: oocytes $(n=110$ Oocytes $)$ matured using synthetic fluid of oviduct (SOF Iraq) with Supplemented. All Maturation media used with supplemented Containing 100 IU/Ml penicillin, $100 \mathrm{mg} / \mathrm{mL}$ streptomycin and 100 $\mathrm{IU} / \mathrm{mL}$ Nystatin. The culture dishes were placed in a $\mathrm{CO} 2$ incubator $(95 \%$ relative humidity, $5 \% \mathrm{CO} 2$ at $38.5^{\circ} \mathrm{C}$ ) for $24 \mathrm{~h}$. Maturation of oocytes was evaluated after $24-28 \mathrm{~h}$ of culture to access the degree of cumulus cell expansion under a stereo zoom microscope and also the appearance first polar body as good indicator for maturation oocyte, number of matured oocytes were counted and recorded. Using the methods described by (38). Figure (3 A, B ) shows first polar body.

\section{Statistical Analysis}

Data were pooled and analyzed by Chisquare test using SPSS 22.0 statistical software (2013).

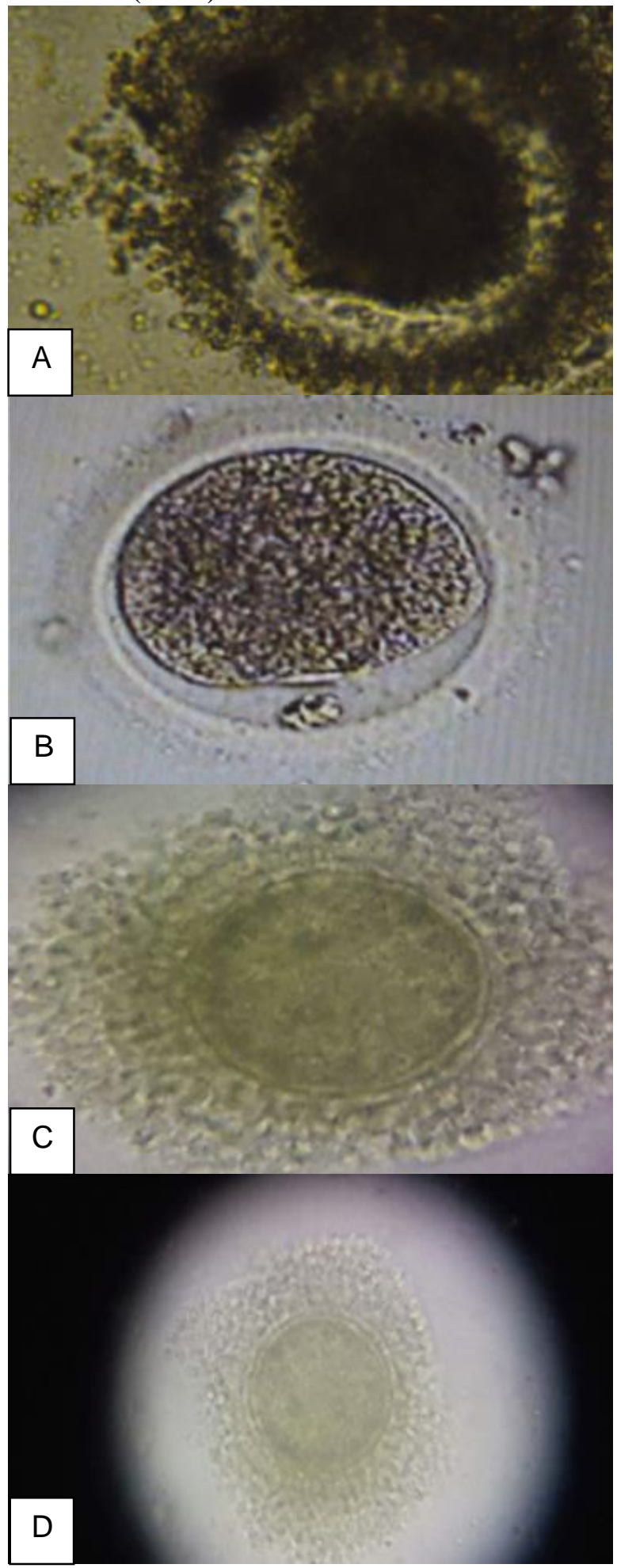

Figures (4): A, B, C and D Oocyte Maturation with cumulus cell expansion and polar body, $(10 \mathrm{X})$. 


\section{Al-Qadisiyah Journal of Veterinary Medicine Sciences \\ (P-ISSN 1818-5746/ E-ISSN 2313-4429) \\ www.qu.edu.iq/journalvm}

\section{Results}

Collection of oocytes Techniques:-

Oocytes were classified into three different grades (A,B and C) depending on the basis of homogenous ooplasm and the compactness of the cumulus cells only The oocytes of Grades (A and B) were used for in vitro maturation. Data on the collection of COCs by aspiration and slicing are presented in Table 1. In total, 345 quality COCs were recovered from 260 ovaries.
The study revealed that slicing method yielded significantly higher number of oocytes 220 distribution Grad A ,B,C 90 $(40.90 \%) \quad, 50 \quad(22.7 \%) \quad, 80 \quad(36.4 \%)$ respectively while the aspiration method 125 distribution Grad A,B,C 40(32\%), $35(28 \%), 50(40 \%)$ respectively there was significant difference $(\mathrm{P}<0.01)$ the recovered of oocyte between two method.

Table (1): The recovery method on quality of buffalo follicular oocyte types obtained for in vitro maturation.

\begin{tabular}{|c|c|c|c|c|c|}
\hline Method & No. of ovary & No. of oocyte & $\begin{array}{c}\text { no and } \\
\text { percentages of } \\
\text { grad -A- } \\
\text { oocyte }\end{array}$ & $\begin{array}{c}\text { no and } \\
\text { percentages of } \\
\text { grad - B- oocyte }\end{array}$ & $\begin{array}{c}\text { no and } \\
\text { percentages of } \\
\text { grad -C- } \\
\text { oocyte }\end{array}$ \\
\hline Aspiration & 100 & 125 & $40(32 \%) \mathrm{Bb}$ & $35(28 \%) \mathrm{Bb}$ & $50(40 \%) \mathrm{Ba}$ \\
\hline Slicing & 160 & 220 & $90(40.90 \%) \mathrm{Aa}$ & $50(22.7 \%) \mathrm{Ab}$ & $80(36.4 \%) \mathrm{Aa}$ \\
\hline
\end{tabular}

$\mathrm{X} 2=\mathbf{2 1 . 9 2 7}=\mathrm{p}<0.01$

Different small letter mean significant difference $(p<0.01)$ within group

Different capital letter mean significant difference $(p<0.01)$ between groups

\section{Culture Media: - Effect}

The percentages of buffalos oocytes that showed cumulus cell expansion and appearance first polar body in TCM-199 and SOF IVM media are presented in Table (2).215oocyte Only culture (grade A and B) oocytes were used for IVM and the maturation rate was assessed according on the cumulus expansion and the appearance first polar body. Used of 105 oocytes cultured in TCM- 199, 35 oocytes showed cumulus expansion with first polar body. The percentages $33.33 \%$ (105/35) percent. In SOF IVM medium, out of 110 oocytes cultured only 16 oocytes showed cumulus expansion with appearance first polar body The percentages $13.91 \% \quad(110 / 16)$, the Overall percentages of buffalo oocytes in two media $23.72 \%(215 / 51)$. There was significant difference $(\mathrm{p}<0.01)$ between different media.

Table (2): The Effect Culture Media on buffalo follicular oocyte types obtained for in vitro maturation

\begin{tabular}{|c|c|c|c|}
\hline Media & $\begin{array}{c}\text { No. of oocyte } \\
\text { cultured }\end{array}$ & $\begin{array}{c}\text { No. and Percentages of } \\
\text { oocyte maturation rate }\end{array}$ & $\begin{array}{c}\text { No. and Percentages } \\
\text { of oocyte maturation rate }\end{array}$ \\
\hline $\begin{array}{c}\text { TCM-199 with FSH } \\
\text { and BSA }\end{array}$ & 105 & $35(33.33 \%) \mathrm{Ab}$ & $70(66.7 \%) \mathrm{Ba}$ \\
\hline $\begin{array}{c}\text { SOF with FSH and } \\
\text { BSA }\end{array}$ & 110 & $16(13.91 \%) \mathrm{Bb}$ & $94(86.5 \%)$ \\
\hline Over all & 215 & $51(23.72 \%)$ & $164(76.3 \%)$ \\
\hline
\end{tabular}

Different small letter mean significant difference $(\mathrm{p}<0.01)$ within group

Different capital letter mean significant difference $(p<0.01)$ between groups

$\mathrm{X} 2=\mathbf{1 0 . 4 8 0}=\mathrm{p}<0.01$

\section{Discussion}

Collection of oocytes Techniques:-

The quantity and the quality of oocytes recovered per ovary are important considerations in the production of IVMIVF embryos. The present study shows that the oocyte recovery rate from 
slaughterhouse ovaries was better with slicing than the aspiration, Similar recovery rates were observed in a studies on buffalo , which is in agreement with earlier findings reporting greater numbers of COCs/ovary with the slicing method than with aspiration, This result agreement with (6) reported that better quality oocytes were recovered per ovary in buffalo by scoring (2.6) than by puncture (1.3) or aspiration (0.9) methods (9) reported Lower COC recovery via the aspiration method might have been because oocytes were recovered from selected follicles $(2-3 \mathrm{~mm})$ on the ovarian surface, and follicles were limited in number. (6) Mansion Buffalo ovaries have a fewer follicles, (10) fewer follicles are recruited in each cycle, (8). In comparison to a stock of 50,000 primordial follicles in cattle ovaries at the time of puberty (7) the number of these follicles in buffaloes has been reported to be only 12,000-19,000. (8) Mansion that Slicing the ovarian surface recovered COCs from follicles of every size, even from the follicles deep in the ovarian cortex, $(1,2$, 11) reported that oocytes were recovered via aspiration from $55 \%$ of follicles, as compared to the slicing method, which recovered oocytes from $78 \%$ of follicles from buffalo ovaries. The superiority of the slicing method over that of aspiration and puncture for recovering oocytes in the present study is in agreement with the results obtained by $(12,13,17,19)$.

\section{Culture Media}

The present study it was observed that buffalo oocytes showed significant variation $(p<0.01)$ in the percent of cumulus cell expansion and appear polar body when matured in TCM-199 and SOF media, This result which is in agreement with earlier

\section{References}

1-Nandi S, Raghu HM, Ravindranatha BM, Chauhan MS. Production of buffalo (Bubalus bubalis) embryos in vitro: premises and promises. Reprod. Domest. Anim., (2002); 37: 65-74.

2-Agrawal SK, OS Tommer (1998). Reproductive technologies in ffalo. Indian Veterinary Research Institute, Izatnagar, Barielly, UP, India. findings reporting, $(26,28,37)$ suggested that a significantly higher percent of buffalo oocytes maturation in TCM-199 medium when compared to SOF medium. (13) reported percentage values $(89.1 \pm 3.5 \%)$ of maturation buffalo oocyte in TCM-199 medium , (14) reported 74 percent maturation rate for bovine oocytes cultured in TCM-199 supplemented with $10 \%$ bovine estrus serum (BES), $(15,16)$ also reported a maturation rate of $76 \%$ when oocytes were matured in TCM-199 supplemented with hormones and BES, these results are dis agreement with $(15,18)$ reported percentage values $(74.82 \%)$ of maturation buffalo oocyte in TCM-199 medium, Previous studies on buffalo oocyte maturation in vitro have shown TCM-199 to be better over Hams F-10 (16). The beneficial effect of TCM-199 on IVM may be related to some factors in its composition such as essential amino acids and glutamine that stimulate DNA and RNA synthesis and enhance cell division $(17,19)$ The percentage of maturation rates in TCM-199 with hormones (77.44+-0.68) than in Ham's F-12 (32.85-0.83). (29, 37, 38) The percentage of maturation rates in TCM-199 with supplement BSA (71.3\% on average). Moreover, these results are in agreement with those obtained by $(32,34,36,39,46)$ who recorded beneficial effect of serum supplementation on in vitro maturation rate of buffalo oocytes. This might be attributed to the action of serum that promotes cumulus cells-oocyte uncoupling by retaining the hyaluronic acid within the COCs in a manner that results in cumulus mucification. This uncoupling could be responsible for stopping the transfer of oocyte maturation inhibition factor via gap junction (47).

3-Haldar A, BS Prakash. Effect of exogenous and minerals in late maturing buffalo heifers (Bubalus bubalis). J. Anim. Physiol. Anim. Nutr., (2007); 91: 326-332.

4-Gasparrini B, Neglia G, Di Palo R, Campanile G, Zicarelli L. Effect of cysteamine during in vitro 


\section{Al-Qadisiyah Journal of Veterinary Medicine Sciences \\ (P-ISSN 1818-5746/ E-ISSN 2313-4429) \\ www.qu.edu.iq/journalvm}

maturation on buffalo embryo development. Theriogenology. (2002); 54, 1537-1542.

5-Leibfried-Rutledge M, ES Crister, JJ Parrish, NL First in vitro maturation and fertilization of bovine oocytes. Theriogenology, (1989); 31: 61-74.

6-Gordon I (2003). Laboratory production of cattle embryos: Maturing the oocyte, 2th edition, Cambridge, MA 02138, CABI publishing.

7-Totey SM, Singh G, Taneja M, Pawshe $\mathrm{CH}$, Talwar GP. In vitro maturation, fertilizationand development of follicular oocytes from buffalo (Bubalus Bubalis). J. Reprod. Fertil. (1992); 95, 597-607;

8-Jamil H, Samad HA, Qureshi ZI, Rehman NU, Ladhi LA. Harvesting and evaluation of riverine buffalo follicular oocytes. Turk. J. Vet. Anim. Sci. (2008); 32: 25-30.

9-Jamil H, HA Samad, NU Rehman, ZI Qureshi, LA Lodhi. In vitro Maturation and Fertilization of Riverine Buffalo Follicular Oocytes in Media Supplemented with Oestrus Buffalo Serum and Hormones. Acta Vet. Brno, (2007); 76: 399-404.

10-Raza A, Samad HA, Rehman NU, Zia euh. Studies on in vitro maturation and fertilization of Nili-Ravi buffalo follicular oocytes. Int. J. Agri. Biol. (2001); 3: 503-506.

11-Khairy MA Zoheir1*, Abdoon AS1, Mahrous KF1 Amer, MA1 Zaher, MM3 Li-Guo, Yang4 and El- Nahass, E. M. 2007. Effects of season on the quality and in vitro maturation rate of Egyptian buffalo (Bubalus bubalis) oocytes

12-Hammam AM, Whisnant CS, Elias A, Zaabel SM, Hegab AO, Abu-El-Naga EM. Effect of media, sera and hormones on in vitro maturation and fertilization of water buffalos (Bubalus bubalis).J. Anim. Vet. Adv., (2010); 9:27-31.

13-Barkawi SA Ibrahim, G Ashour, Amal K ElAsheeri, YM Hafez, Marwa S Faheem. in vitro production of buffalo (Bubalus bubalis) embryos Animal Production Department, Faculty of Agriculture, Cairo University, Giza, Egypt, Postal Code: 12613 Egyptian J. Anim. Prod., (2007); 44(1):35-48

14-Hegab AO, AE Montasser, AM Hammam, EMA Abu El-Naga, SM Zaabel. Improving in vitro maturation and cleavage rates of buffalo oocytes. Anim. Reprod. (2009); 6(2): 416-421.

15-Lemuel M Aquino, Fely V Manaois II1, Lerma C. Ocampo2 and Marlon B. Ocampo1, 2. Evaluation of bioassay using in vitro matured water buffalo oocytes in predicting bull sperm fertility Journal of Agricultural Technology (2015); Vol. 11(8): 2531-2538 Available online http://www.ijataatsea.com ISSN 1686-9141

16-Nagina1 A Asima, U Nemat, A Shamim1 Effect of melatonin on maturation capacity and fertilization of Nili-Ravi buffalo (Bubalus bubalis) oocytes Open Veterinary Journal, Vol. 6(2):
(2016); 128-134 ISSN: 2226-4485 (Print)ISSN: 2218-6050 (Online)

17-Waheed KH El-Shahat, AM Hammam. Effect of oocytes quality, protein additlives, hormonal supplement and type of capacitation agents buffalo bulletin Vol.35 No.3 (2016).

18-Srinivasa PCH, A Palanisamy, VS Gomathy, S Sathesh kumar, A Thangavel, G Dhinakar Raj. Effect of TCM-199 and synthetic oviductal fluid (SOF) medium and cysteamine supplementation to in vitro maturation media on maturation, cleavage rate and subsequent embryonic development of buffalo oocytes. Buffalo Bull., (2013); 32(3):182188.

19-Mahmoud KGHM, Al-Shimaa Al-HH El-Naby. Factors affecting Buffalo Oocytes Maturation. Global Veterinary. (2013); 11(5): 497-510.

Barakat IAH, SA Kandeal, HM El-Ashmaoui, A Barkawi, E EL-Nahass. Effect of medium type and luteinizing hormone $(\mathrm{LH})$ on in vitro maturation of Egyptian buffalo oocytes. African J. of Biotechnol., (2012);11(20): 4620-4630.

20-Barakat IAH, SA Kandeal, HM El-Ashmaoui, A Barkawi, E EL-Nahass. Effect of medium type and luteinizing hormone (LH) on in vitro maturation of Egyptian buffalo oocytes. African J. of Biotechnol. (2012);11(20): 4620-4630.

21-Sadeesh EM, F shah, AK Balhara, SMK Thirumaran AN, SYadav, PS Yadav. Effect of growth factor and antioxidant on in vitro maturation of oocytes and cleavage rates of in vitro produced Indian buffalo (Bubalus bubalis) embryos. Vet. Arhiv (2014); 84, 459-474

22-Swati ruhil, GN Purohit*In vitro fertilization of buffalo oocytes matured in vitro in three different media Indian Journal of Animal Reproduction 36 (2) : Dec 2015

23-Yosef Deneke, Prem Singh Yadav, Rajib Deband Trilok Nanda4. comparative studies of the effect of BSA VS FCS AS A supplement in TCM-199 on the in vitro maturation rate of buffalo oocytes collected from slaughterhouse ovaries, buffalo bulletin, (2013); Vol.32 No.1

24-Mehmood A, Anwar M, Andrabi SMH, Afzal M, Naqvi SMK. In vitro maturationand fertilization of buffalo oocytes: the effect of recovery and maturation methods. Turkish J. Vet. Anim. Sci., (2011); 35: 381-386.

25-Miller Y, Robertson S (1959). Cited by; Sisson, S. (1975) the anatomy of the domestic animal.

26-Warriach HM, Chohan KR. Thickness of cumulus cell layer is a significant factor in meiotic competence of buffalo oocytes. J. Vet. Sci., (2004); 5: 247-251.

27-Süss U, Madison V. Morphology and meiotic development of bovine oocytes cultured in vitro. Arch. Androl., (1983); 11: 217-218. 


\section{Al-Qadisiyah Journal of Veterinary Medicine Sciences \\ (P-ISSN 1818-5746/ E-ISSN 2313-4429) \\ www.qu.edu.iq/journalvm}

28-Khandoker MAMY, Imai K, Takahashi T, Hashizume K. Role of gelatinase on follicular atresia in the bovine ovary. Biol. Reprod. (2001); $65,720-732$.

29-Totey SM, Singh G, Taneja M, Pawshe CH, Talwar GP. In vitro maturation, fertilization and development of follicular oocytes from buffalo (Bubalus bubalis). J. Reprod. Fertil., (1992); 95: 597-607.

30-Kobayashi K, S Yamashita, H Hoshi (1994). Infl uence of epidermal growth factor and transforming growth factor- $\alpha$ on in vitromaturation of cumulus cell-enclosed bovine oocytes ina defi ned medium. J. Reprod

31-Totey SM, Pawshe CH, Singh GP. In vitro maturation and fertilization of buffalo oocytes (Bubalus Bubalis): Effects of media, hormones and sera. Theriogenology. (1993); 39: 1153-1171;

32-Das GK, Jain GC, Solanki VS, Tripathi VN. Efficacy of various collection methods for oocyte retrieval in buffalo. Theriogenology, (1996); 46: 1403-1411.

33-Singh R, Majumdar AC. Chronological changes of buffalo follicular oocyte maturation in vitro. Indian J. Anim. Sci., (1992); 62: 205-209.

34-Khan IQ, Samad HA, Rehman NU. Quantity and quality of buffalo follicular oocytes recovered by aspiration and scoring methods for in vitro studies. Pak. Vet. J., (1997); 17: 187-189.

35-Totey SM, Singh G, Taneja M, Talwar GP. In vitro maturation and fertilization of follicular oocytes from buffalo.Theriogenology, (1991); 35: 284.

36-Donald LE. Veterinary Endocrinology and Reproduction, $2^{\text {nd }}$ edn., Lea \& Febiger, Philadelphia, USA, 1975; 253.

37-Danell B. Oestrous behavior, ovarian morphology and cyclical variation in follicular system and endocrine pattern in water buffalo heifers. Unpub. Ph.D. Thesis, Swedish University of Agricultural Sciences, Uppsala, Sweden. (1987).
38-Arlotto TM, Leibfried-Rutledge ML, First NL. Size distribution and meiotic competence of bovine primary oocytes from two locations in the ovary. Theriogenology, (1990); 33: 188.

39-Sharma D. In vitro maturation and fertilization of buffalo oocytes. M.V.Sc. Thesis. Indian Vet. Res. Inst., Izatnagr (UP), India. (1990).

40-Datta TK, Goswami SL. Feasibility of harvesting oocytes from buffalo (Bubalis bubalis) ovaries by different methods. Buffalo J., (1998); 14: 277-284.

41-Fukuda Y, M Ichikawa, K naito, Y Toyada. Birth of normal calves resulting fron bovine oocytes matured, fertilized and cultured with cumulus cells in vitro up to blastocyst stage. Biol. Reprod., (1990); 22: 669

42-Totey SM, CH Pawshe, GP Singh. In vitro maturation and fertilization of buffalo oocytes (Bubalus bubalis): Effect of media,hormone and sera. Theriogenology, (1993); 39: 1153-1171.

43-Holm P, Booth PJ, Schmidt MH, Grevet A, Callesen H. High bovine blastocyst development in a static in vitro production system using SOFaa medium supplemented with sodium citrate and myo-inositol with or without serum-proteins. Theriogenology, (1999); 52:683-700.

44-Curnow EC, Pawitri D, Hayes ES. Sequential culture medium promotes the in vitro development of Macaca Fascicularies embryo to blastocyst. Am J Primates, (2002); 574:203-212.

45-Hakan S, Mehmet Y, Zakariya N, Mustafa KS. Replacement of fetal calf serum with synthetic serum substitute in the vitro maturation medium: effect on maturation fertilization and subsequent development of cattle oocytes in vitro. Turk $\mathbf{J}$ Vet Anim Sci, (2004); 28:779-784.

46-Eppig JJ. Role of serum in FSH stimulated cumulus expansion by mouse oocytes cumulus cells complexes in vitro. Biol Reprod, (1980); 22:629-633.

47-Gordon I (1995). Laboratory Production of Cattle Embryos. Wallingford, UK: CAB international. 